\title{
O trabalho, essência do homem? O que é o trabalho?*
}

\author{
Eugène Enriquez ${ }^{1}$ \\ Universidade Paris-Diderot, Paris 7 (Paris, França)
}

\begin{abstract}
Neste texto, o autor se pergunta se o trabalho é a essência do homem. A resposta é negativa. Muitos outros atributos, como a linguagem, o lazer, a religião, a guerra... entram na constituição do humano. No entanto, em nossas sociedades modernas, o trabalho ocupou um grande espaço na vida do homem. Ora, o que é o trabalho? O autor tenta dar uma resposta a essa questão e evoca as condições que devem ser respeitadas para que o trabalho não continue sendo o signo mais evidente da alienação humana.
\end{abstract}

Palavras-chave: Trabalho, ócio, religião, alienação, ação, vida.

Contrepoint: le travail, essence de l'homme? Qu'est-ce que le travail?

Dans ce texte, l'auteur se demande si le travail est l'essence de l'homme. Sa réponse est négative. Bien d'autres attributs: le langage, le loisir, la religion, la guerre... entrent dans la constitution de l'humain. Néanmoins le travail a pris une large place dans la vie de l'homme dans nos sociétés modernes. Or qu'est-ce que le travail? L'auteur tente de fournir une réponse à cette question et évoque les conditions à respecter pour que le travail ne soit plus le signe le plus évident de l'aliénation humaine.

Mots-clés: Travail, oisiveté, religion, aliénation, action, vie.

Counterpoint: work as the essence of man? What is work about?

In this article, the author wonders whether work is the essence of man. His answer is negative. Many other attributes such as language, leisure, religion, war are parts of the mankind essence. However, work occupies an important place in the human life in our modern societies. Now, what is work about? The author tries to give an answer to this question and proposes the conditions which should be respected if one wants that work does not continue to be the most obvious sign of human alienation.

Keywords: Work, idleness, religion alienation, action, life.

\section{Introdução}

$\mathrm{D}$ esde que Marx (1846) declarou que o elemento diferencial entre o animal e o homem era que este era capaz de "produzir suas condições de existência", de transformar o mundo, e assim não mais se submeter aos puros acasos da natureza, o trabalho é considerado, tanto por marxistas quanto por não marxistas, não só como uma característica importante da espécie humana, mas como a essência do homem. Numa perspectiva sócio-histórica, podemos afirmar que, desde o advento do capitalismo e da revolução industrial do século XVIII, o trabalho tornou-se um atributo central da vida humana nas sociedades ocidentais. Ao falarmos da essência do homem, passamos, portanto, de uma perspectiva psico-sócio-histórica a uma visão ontológica. Vamos portanto nos perguntar, na primeira parte deste texto, se tal visão reflete a verdade do homem, o que nos levará, na segunda parte, a definir melhor aquilo que o trabalho se tornou.

\footnotetext{
* Publicado originalmente na seção "contraponto" do número especial sobre psicossociologia do trabalho da Nouvelle Revue de Psychosociologie , 15 (1), 253-272, 2013. DOI: 10.3917/nrp.015.0253
}

1 Professor emérito de Psicossociologia, Universidade Paris-Diderot (Paris 7). 


\section{A visão ontológica}

Nossa resposta ao questionamento sobre o fato de o trabalho ser ou não a essência do homem será, desde já (vamos justificar, é claro, nossa posição), totalmente negativa. Isso não significa que outros elementos possam inscrever-se com vantagens em seu lugar; significa simplesmente que o ser humano é provido de numerosos atributos e que não há nenhum motivo, sociológico ou ontológico, para pensarmos que alguns deles são mais fundamentais que outros. Sem dúvida, a lista que propomos aqui não é exaustiva. De qualquer forma, ela não implica, em nossa opinião, qualquer supremacia (ainda que determinados autores a estabeleçam) de um atributo sobre outro.

\section{O homem é um ser de linguagem}

Todos os homens possuem uma linguagem (existem centenas de línguas e outras milhares já existiram), por mais bizarras e rudimentares que sejam. "Honra dos homens, Santa linguagem", escreveu Paul Valéry, que sabia do que estava falando. "Honra dos homens" porque a linguagem permite a passagem da força física ao conflito metabolizado, ao diálogo, à conversa, ao jogo, ao debate e à controvérsia. A palavra emerge e toma seu lugar "quando as lanças estão guardadas", escreveu, por sua vez, Marcel Mauss (1924).

A linguagem é indispensável para falar consigo mesmo (monólogo interior, introspecção, autoanálise), para explorar nosso "foro interior", nossos "abismos" (Victor Hugo) ou, simplesmente, nossos sentimentos profundos ou superficiais. É certo que esse diálogo interior é uma invenção relativamente recente - os gregos, por exemplo, não concebiam ou reprovavam a dissociação entre o pensamento íntimo, por um lado, e as palavras e os atos, por outro (Starobinski, 1974). ${ }^{2}$ Sabemos agora de toda a sua importância, não só na literatura (de Édouard Dujardin, inventor do "monólogo interior" a Proust, Joyce, Virginia Woolf ou Nathalie Sarraute), mas também na vida cotidiana do cidadão médio.

A linguagem está sobretudo na base da comunicação com o outro (dando ao termo "comunicação" o sentido mais amplo que lhe atribuiu Claude Lévi-Strauss, 1950), seja o outro uma pessoa, um grupo próximo ou uma cultura profundamente diferente. Sem linguagem comum (ou, quando dois "conjuntos" não falam a mesma língua, sem a busca de uma linguagem comum), não há comunicação, não há dom de palavras, não há dom ou troca de bens ou de serviços, de rituais, de festas ou de mulheres. Isso significa o recolhimento sobre si mesmo, sobre seu grupo, sua confraria, sua capela, sua seita. Daí vem o "entre-si" (e seu calor sufocante) e, enfim, a endogamia, porta para o incesto e a dificuldade ou mesmo a impossibilidade de criar laços sociais, pois qualquer grupo fechado é atravessado por tendências paranoicas (Castoriadis 1999; Zaltzman, 1998). ${ }^{3}$

Como base para essas afirmações, evocamos o ótimo livro de antropologia social de Malinowski, Os argonautas do Pacífico Ocidental (1922), em que ele descreve o comércio da Kula entre os habitantes de Dobu e os das ilhas Trobriand. No passado, esses dois povos já tinham se enfrentado, e se lembram disso. Têm medo um do outro. Não falam a mesma língua. No entanto, um deles, os Trobriandenses, arrisca-se a entrar no mar para ir a Dobu, levando, de presente, pulseiras de conchas (mais tarde, os habitantes de Dobu retribuirão o presente com colares de conchas). Ao abordar a ilha, os Trobriandenses rendem arrebatados elogios a seus anfitriões, pois não se sentem nem um pouco seguros. Encantamentos preventivos fazemse necessários: "Minha mãe já não é deste mundo, é você, mulher de Dobu; meu pai já não é deste mundo, é você, homem de Dobu". Os habitantes de Dobu ficam encantados. Como

2 Aquiles, que recusa as ofertas de Agamenon, comunicadas por Ulisses, exclama: "odeio tanto as portas do Hades quanto aquele que esconde uma coisa no peito e tem outra nos lábios” (Homero, Ilíada, Canto IX, citado por Starobinski, 1974).

3 Cornélius Castoriadis (1999) vai mais longe, quando diz que qualquer cultura tem essência paranoica. Bem como Nathalie Zaltzman, ao escrever que a realidade (em nossa sociedade) tende a se tornar paranoica (Zaltzman, 1998). 
escreve Malinowski: "esse ato tão simples, essa entrega de dois objetos sem significados e que não servem para nada tornou-se a base de uma relação intertribal". Com efeito, a palavra compromete e todo mundo a respeita. E Lévi-Strauss, comentando Malinowski, pode escrever: "A Dádiva recíproca realiza a passagem da hostilidade à aliança, da angústia à confiança, do medo à amizade" (1947).

A linguagem tem outras virtudes. Quando se exprime por meio de uma palavra fundamental, ou seja, de uma palavra criadora que dá nome aos seres e às coisas, como Adão deu nome às formas vivas do paraíso, ou de uma metáfora que liga elementos (termos) que não tinham nenhum motivo para se unir (ou seja, uma palavra poética), ela gera uma nova realidade, surpreendente, às vezes insólita. De qualquer forma, ela favorece uma verdadeira revelação que leva à exaltação, e, acima de tudo, a outra maneira de perceber, de sentir, de pensar. "As palavras fazem o amor", dizia André Breton. Nessa hora, aquele que fala, o escritor, comporta-se como um verdadeiro Dichter, palavra alemã cujo equivalente francês "poeta" diz bem menos. O Dichter, "para Canetti, talvez mais do que para qualquer outro ser humano, tem uma responsabilidade com relação à vida. Seu ministério primeiro, a cada instante, é o de oporse à morte. Trata-se de um ato moral, talvez o ato moral por excelência" (Steiner, 1997). Mallarmé já dizia: "dar um sentido mais puro às palavras da tribo" e assim escrever uma nova página na vida de todos os seres humanos. Os surrealistas, por sua vez, perceberam bem a função instauradora, instituidora da palavra, que é, para além da simples comunicação (que pode também criar laços de simpatia, amizade e amor), a de fazer que surja outro mundo, um mundo no qual o maravilhoso (banido da vida cotidiana, em que assassinatos e catástrofes vivem a nos sufocar) terá seu lugar garantido.

Sem uma linguagem articulada, constantemente renovada, frequentemente inventada, de fato não passaríamos (e olhe lá!) de animais aperfeiçoados. A linguagem nos dá acesso ao universo da cultura (da saída da animalidade) e nós transformamos a cultura pela linguagem. Dessa forma, a linguagem é uma das características essenciais da espécie humana.

\section{A amizade e o amor}

Desde os precursores da sociologia (particularmente Saint-Simon, Comte - que, tendo inventado o termo "sociologia", pode ser classificado nesta categoria - e Fourier, mas principalmente desde Freud), sabemos que o amor é a matriz do laço social. É impossível aprofundar aqui esse tema, do qual tratamos em nossa obra Les tumultes de l'amour (Enriquez, 2012), à qual remetemos o leitor. Hegel já havia percebido isso ao evocar, em sua primeira "Filosofia do Espírito", a dialética dos amantes como instauradora do reconhecimento mútuo. Os antigos (gregos e romanos) diziam (exceto Empédocles e Platão) que a amizade prevalecia sobre o amor (La Fontaine, formado pela leitura dos antigos, escreve: "um verdadeiro amigo é uma coisa graciosa"). De qualquer forma, sem amizade e sem amor ou, pelo menos, sem um mínimo de simpatia (Tocqueville), o homem seria um verdadeiro lobo para o homem e nenhuma sociedade duradoura poderia existir.

É pelo fato de as pessoas se amarem (ainda que pouco) que elas podem criar seus filhos e amá-los, carregá-los, acarinhá-los e fazer que se tornem seres humanos. Os trabalhos de Spitz (1950) sobre o hospitalismo e os de Winnicott demonstraram que, sem amor, carinho e afeição, as crianças definhavam e corriam o risco de morrer. Estes são trabalhos bem conhecidos, que não precisamos aprofundar aqui. Quanto às relações sociais cotidianas que exigem que todos saibam conversar, dialogar, fazer favores uns aos outros, compartilhar refeições, é preciso pelo menos que alguns fragmentos do Eros estejam presentes, para que as instituições, as organizações e os grupos permaneçam como conjuntos vivos, nos quais cada um, coordenando seus esforços com os outros, possa esperar ser reconhecido, considerado, estimado (ainda que muitas vezes fique decepcionado). $\mathrm{O}$ amor, tal como o concebemos hoje, deve ter nascido por volta do século XII, segundo os especialistas da Idade Média. Por sua vez, Eros sempre existiu 
(assim como a indiferença e o ódio) e tem que lutar, continuamente, contra as tendências à vitória das pulsões de morte que nos condenariam à destruição ou à autodestruição. Para que a vida continue, para que as relações sociais sejam sustentáveis, é preciso, como dizia Bichat (atualmente representado por G. Canguilhem, 1966), mobilizar todas as forças opostas à morte. Tal condição não pode ser descartada. Os povos que acreditaram no contrário (os países de totalitarismo delirante) acabaram por definhar ou quase desapareceram.

\section{O lazer, o ócio e a dedicação ao bem público}

Durante muito tempo, o trabalho foi considerado uma obrigação, um ônus (vamos deixar de lado sua origem, tripalium, continuamente relembrada por inúmeros autores) provocado pela necessidade (Ananké) de comer e se abrigar. No entanto, as sociedades "arcaicas" (a dos caçadores-coletores) trabalhavam pouco. Até mesmo as últimas sociedades desse tipo, que restaram e que passaram pela "revolução neolítica" (agricultura e criação de animais), consagraram pouco tempo a essa atividade. Assim, os Nuers (tribo africana) estudados pelo antropólogo inglês Evans-Pritchard (1971) ${ }^{4}$ :

[...] por volta das $7 \mathrm{~h}$, acompanham, durante cerca de meia hora, o rebanho ao pasto (raramente ficam mais do que dois ou três com o rebanho, cada família se reveza mandando um de seus homens); por volta das $14 \mathrm{~h} 30$, eles viram o esterco com grandes bastões; às 16h30, acendem o fogo em casa; por volta das $17 \mathrm{~h}$, prendem o gado. No mais, eles passam o tempo todo abrigados em seu quebra-vento.

As tribos Tupi-Guarani (ou Guayaqui) analisadas por Clastres $(1974)^{5}$ trabalham ainda menos:

[...] o grosso do trabalho, efetuado pelos homens, consistia em limpar, com machados de pedra e com fogo, a superfície de terra necessária. O cumprimento dessa tarefa, ao final da estação chuvosa, ocupava os homens durante um ou dois meses. Daí resulta, portanto, esta alegre conclusão (nós é que a destacamos): os homens trabalhavam cerca de dois meses a cada quatro anos. Quanto ao resto do tempo, dedicavam a ocupações não sentidas como penosas, mas como prazerosas: caça, pesca, festas e bebedeiras; e satisfazendo seu gosto apaixonado pela guerra.

Evans-Pritchard e Clastres indicam, é claro, que o restante do processo agrícola e de criação de animais cabe às mulheres, que, por sua vez, não têm qualquer lazer - já que, além de fazer esse trabalho, também têm de preparar as refeições e cuidar dos filhos. Essa é uma prova de que a dominação masculina não esperou a expansão do capitalismo para se impor radicalmente. ${ }^{6}$ Nisso se baseia nossa conclusão um tanto quanto ousada: os homens não gostam de trabalhar e só o fazem quando se sentem obrigados, são forçados, ou ainda quando esperam (como em nossas sociedades) ser reconhecidos pelos superiores e colegas das instituições das quais fazem parte, e quando esperam satisfazer sua necessidade de sucesso, orgulho, glória e seu gosto pelo dinheiro que é fonte de prazer.

Esse pouco gosto pelo trabalho é encontrado (seremos breves a respeito desse assunto bem conhecido) nas sociedades que formaram a base da civilização ocidental. São muitos os estudos que destacam a falta de interesse dos cidadãos atenienses pelo trabalho. Em primeiro lugar, o cidadão (daí seu nome) é um homem que cuida dos negócios da cidade e que decide, com os outros cidadãos, a melhor maneira de geri-los. Os outros (camponeses, artesãos, apátridas, escravos) são obrigados a trabalhar. Basta que nos lembremos das queixas que

4 Citados por Enriquez (1983).

5 Citados por Enriquez (1983).

6 Aliás, cabe questionar se a repartição dos encargos entre os dois sexos realmente mudou em nossas sociedades hipermodernas, pois constatamos que a maioria das mulheres, além de seu trabalho assalariado (muitas vezes precário), ficam com a obrigação dos mais variados serviços domésticos. Os maridos, quando existem (as famílias monoparentais são, em sua maioria, famílias cujo pai desertou), sempre ajudam pouco no trabalho doméstico. 
Hesíodo (que era camponês, ainda que poeta) formulou em seu texto Os trabalhos e os dias. Sem dúvida, os "apátridas" às vezes tinham importantes cargos públicos, mas eram considerados "fora da lei". O trabalho não era nada valorizado nessa polis que, no entanto, nos deu as primeiras lições de democracia. O cidadão tem por tarefa (nobre) atuar para que a democracia funcione bem, indo à ágora ou à ecclesia quando há decisões a serem tomadas. Já os não cidadãos têm a tarefa (mais ou menos vil) da produção e da comercialização de bens e serviços.

Como sabemos, esse estilo de vida não era reservado somente à sociedade ateniense. Também foi predominante nas sociedades europeias e asiáticas. Basta nos lembrarmos da divisão entre as três funções essenciais evidenciadas por Dumézil (1940), que caracterizaram nossas sociedades até a Revolução Francesa. A força (os homens de guerra - os nobres de Espada em nossa sociedade), a soberania espiritual (os homens de oração - os padres) e a fecundidade (os homens que penavam - camponeses, artesãos, comerciantes, que se alimentavam como podiam e eram obrigados a alimentar as duas primeiras categorias, aquelas que consideravam o trabalho uma atividade degradante). Naturalmente, sempre houve alguma acomodação com relação a essa divisão fundamental. Junto à nobreza de espada, foi desenvolvida uma nobreza de toga (da qual fizeram parte determinados magistrados, advogados, médicos e escritores). Junto aos padres seculares, havia padres regulares que praticavam em seus monastérios determinadas formas de agricultura e preparavam plantas medicinais. No entanto, essas exceções à regra não impediam os nobres e, em seguida, a burguesia em ascensão (na Inglaterra e na Holanda), de trabalhar muito pouco. ${ }^{7}$

No entanto, a atmosfera havia mudado muito desde o início do século XIX. SaintSimon (notável antecipador dos tempos modernos, ainda muitas vezes desvalorizado) proclamava a necessidade para todos de, enfim, ingressar na Idade Industrial e de começar a trabalhar. Daí vem a famosa fábula das abelhas (os produtores) e das vespas (os ociosos, nobres, padres, aqueles que vivem de renda) exaltando a vitória das abelhas. Os saint-simonianos (apesar de sua ênfase e sua atitude muitas vezes ridícula) levaram muito a sério a mensagem de Saint-Simon e muitos deles foram notáveis construtores (Ferdinand de Lesseps) ou homens de negócios (os irmãos Péreire).

A Marx, admirador de Saint-Simon e crítico severo de Proudhon, nada restava senão apoiar um e ironizar o outro. Todos ao trabalho! Esse trabalho poderia, no entanto, levar a maioria à exploração e à alienação. Mas os operários conscientes e organizados seriam, um dia, capazes de "quebrar suas correntes".

Infelizmente, ainda estamos na Idade Industrial, que ficou mais complexa e à qual se acrescentaram a Idade Comercial (consumo exagerado) e a Idade Financeira (a especulação). O mundo fica alternativamente obcecado pelo crescimento ou pela crise e se pergunta se não está correndo ingenuamente em direção ao abismo (a visão do apocalipse se revela ser menos "alegre" que a visão que os Vienenses tinham durante os anos que antecederam a "Grande Guerra").

No entanto, não faltaram gritos de alarme ou em defesa de outro estilo de vida. Já no fim do século XVIII, Rousseau, no continente, e Samuel Johnson, moralista e lexicógrafo (que teve, na mesma época, considerável influência sobre os costumes e as letras inglesas) na Inglaterra, já haviam feito elogios à perda de tempo, ao ato de sonhar acordado, às caminhadas sem rumo e às conversas descontraídas.

No século XIX, Thoreau, seguido de Lafargue (genro de Marx), Nietzsche e Stevenson, e, no século XX, Russel, Malevitch e Bataille também elevaram-se contra a mística do trabalho

7 Quais são as ocupações dos heróis de Jane Austen? Viver de renda, exibir-se, caçar, passar uma temporada na praia (em Bath), seduzir jovens garotas de boa família, as quais acabam desposando, com quem fundarão uma família numerosa e respeitável. Aí podemos perguntar: o que fazem os protagonistas do imenso romance de Proust (pelo menos a maioria deles) a não ser passear no "Bosque" ou nos Champs-Elysées, visitar uns aos outros, conversar até perder a voz e dedicar-se a seus amores ou a seus desejos sexuais? 
e deram letras de nobreza à ociosidade. Em um breve artigo, é impossível falar dos trabalhos de tantos pensadores e render-lhes as devidas homenagens, por terem sido homens-vigilantes que se deram conta das consequências dessa apologia do trabalho. Segundo eles, ela só podia levar à mutilação dos seres humanos. Esperamos um dia poder dedicar um texto às reflexões estimulantes desses homens apaixonados pela vida. Deixar que passem em branco, no entanto, não nos parece uma escolha com a qual temos de concordar. Por isso, apresentamos a seguir alguns pensamentos esparsos de alguns desses autores.

Lafargue, em O direito à preguiça (1888), destaca a degenerescência da classe operária, obrigada a trabalhar de 12 a 14 horas por dia, e das crianças de 6 a 8 anos que sofrem "a mesma tortura", e incita os operários a se livrar da "paixão moribunda pelo trabalho". Ele aponta, bem antes dos economistas e politólogos clássicos, os riscos do excesso de produtividade, do desperdício e do colonialismo indispensável para escoar a mercadoria excedente. E mostra que o capitalismo, para continuar, tem de criar necessidades fictícias e, portanto, "descobrir consumidores". Ele destaca, bem antes de Althusser e seus "aparelhos ideológicos de Estado", a necessidade que os burgueses têm de desenvolver "profissões ideológicas" para conseguir lidar com as possíveis revoltas do "inimigo interno". Zomba dos burgueses "condenados à preguiça, ao gozo forçado e ao excesso de consumo", o que só faz "crescer a barriga". Reivindica a jornada de trabalho de 3 horas e entoa loas à preguiça, lembrando estes versos bucólicos de Virgilio O Meliboe, Deus nobis hoec otia fecit (Ô Melibeu, Deus nos deu essa felicidade [a ociosidade]) e escrevendo: "Ô preguiça, tenha piedade de nossa longa miséria! Ô preguiça, mãe das artes e das nobres virtudes, seja o bálsamo das angústias humanas".

Bertrand Russel (1932) também evoca as crises de excesso de produtividade, a vontade que as classes dirigentes têm de fazer que os operários trabalhem e o fato de reservarem para si os lazeres às vezes mais estúpidos (caça à raposa!). Ele celebra o espírito lúdico e a importância da cultura (e não da civilização - e nisso ele tem razão, pois a civilização inclui, ao mesmo tempo, cultura e violência - a dominação). Infelizmente, as universidades não estão aptas a ensinar a seus alunos o desejo de fazer pesquisas "seguindo vias inéditas". ${ }^{8}$ Segundo ele, com quatro horas diárias de trabalho, todos teriam tempo de se cultivar, de sentir "a alegria de viver, de ser originais, benevolentes e não guerreiros" (grifos nossos).

Quanto a Rousseau, Nietzsche e Thoreau, sabemos a que ponto gostavam de passear ("Só faço coisas durante meus passeios", disse Rousseau), de caminhar (Thoreau, três a quatro horas por dia; Nietzsche, seis horas) na natureza ("Nosso ethos é o pensamento ao ar livre", disse Nietzsche), única a dar "o sentimento de existência" (Rousseau). Lembremo-nos da bela fórmula de Thoreau (1854): "É vão sentar-se para escrever quando nunca se levantou para viver". Observemos Johnson (1761) responder à objeção de Boswell (seu biógrafo) de que "a ociosidade gera tédio": "Isso ocorre, meu senhor, por que os outros estão ocupados, de maneira que nos falta companhia. Se, pelo contrário, fôssemos todos ociosos, não sentiríamos nenhum tédio, nos divertiríamos uns com os outros". Vamos sonhar com Stevenson (1877), a respeito do "aprendizado na rua" e da ociosidade durante a juventude, "pois os primeiros da classe, em geral, não fazem nada de suas vidas"; e a respeito da importância de "matar aulas", pois "é em seu entorno, e pelo preço de um simples olhar que se aprende o calor, o sorriso da vida e a ser radiante". Ele zomba dos pobres indivíduos ocupados "que talvez jamais encontrem qualquer satisfação e que foram enganados".

Terminemos com Bataille, que escreveu, em A noção de despesa (1930), com a violência que o caracterizava no pré-guerra: "A vida humana... não pode, de forma alguma, ficar limitada aos sistemas fechados que lhe são atribuídos através de concepções razoáveis. $\mathrm{O}$ imenso trabalho de abandono, de escoamento e de tempestade que a constitui poderia ser expresso, dizendo-se que ela só começa quando há falhas desses sistemas... Se houver ordem... é preciso que as forças 'bem ordenadas' se liberem e se percam, para fins que não podem sujeitar-se a

$8 \mathrm{O}$ que diria ele do estado de nossas atuais universidades que matam, pouco a pouco, o mínimo de inventividade que ainda existia há dez anos? 
nada e dos quais seja possível prestar contas...". Ele conclui proclamando: "A insubordinação caracteriza a espécie humana".

\section{Os mitos, as religióes, as ideologias}

Não existem sociedades sem mitos (sem lendas), ${ }^{9}$ sem religiões ou sem ideologias mais ou menos dominantes. Bergson (1932) resumiu essa obrigação social numa fórmula famosa e decisiva: "O homem é uma máquina de fazer deuses", fórmula que pensadores tão diferentes quanto Durkheim e Castoriadis poderiam subscrever. Mas, por que motivos? Simplesmente porque o homem perdido na terra, literalmente "jogado" (Heidegger) num mundo desconhecido, sempre precisou de "avalistas transcendentes", que lhe garantam (ou fazem de conta que garantem) que sua vida não é fruto do mero acaso, não é absurda, e que, portanto, é provida de sentido. Na medida em que o ser isolado não tem condições de dar, encontrar ou ainda de construir uma vida significativa, ele tem a necessidade de se agarrar a uma crença. Aristóteles dizia: "o homem é um ser que tem sede de verdade", mas Castoriadis lhe responde, 24 séculos mais tarde (mesmo sendo um grande admirador de Aristóteles): "Não. O homem tem sede é de crença". Ele tem a necessidade de acreditar em algo que o ultrapasse e que legitime sua vida na Terra. Esse "algo" será, de acordo com os períodos históricos e de acordo com as pessoas (porque cada ser humano representa, como disse enfaticamente Fourier, um "distanciamento absoluto" com relação a todos os outros, distância biológica, histórica, psicológica, sociológica que ele não é capaz de preencher - não existe o "mesmo", o mais semelhante sempre é, pelo menos em determinados aspectos, dessemelhante), um mito fundador da tribo (acompanhado por uma série de rituais), um mito do herói (os mitos atendem sempre a uma dupla necessidade: de confirmar a segurança e a coerência intelectual - é por isso que essa tribo ou essa sociedade existem), permitindo que todos tenham uma visão unificada e comum do universo e de seu lugar no cosmo - além de um contágio afetivo (eis os exemplos que todos devem respeitar e imitar, mesmo sabendo que é impossível ser tão bom, tão puro quanto os fundadores ou os heróis, mas sentindo também, em sua intimidade, que é através da tentativa de se parecer com eles que cada um pode se erguer e sair, em parte, de sua condição de "pequeno homem") - uma religião ou uma ideologia que tem a mesma estrutura e a mesma função que a religião, nos lugares em que a religião está em declínio (o país, a terra - a terra não mente, dizem os tradicionalistas - a nação, a pátria ou até mesmo a seita). Assim, os homens precisam de crença e de ilusão. E quanto mais forte é a crença, mais os indivíduos são "sequestrados pela crença" (Roy, 1998), quanto mais a ilusão é sólida, reforçada por rituais, e principalmente pelos dogmas que dão sentido prévio a todos os seus atos, mais eles se sentem livres da ingrata tarefa de buscar e dar sentido a sua vida, e podem dormir seu "sono dogmático".

Somente alguns aderem aos preceitos de Stendhal (em sua correspondência): "Se a vida deixasse de ser uma busca, ela não seria mais nada)"; não sentem a necessidade de serem consolados, tranquilizados, não tem a "nostalgia do pai" (Freud, 1927); vivem sem a esperança de um mundo futuro celeste ou terrestre, mas fazem tranquila ou dolorosamente sua "longa e pesada tarefa" (Vigny), combatem e trabalham como se isso servisse para alguma coisa, ${ }^{10}$ não precisam nem de mitos, nem de religiões, nem de ideologias fortes. Estes sabem que o presente é o único dom que recebem e se contentam com ele.

\footnotetext{
9 "Os países sem lendas estão condenados a morrer de frio" (Patrice de la Tour du Pin).

10 Em Bhagavad-Gita, Krishna diz a Arjuna: "Combata como se o combate servisse para alguma coisa, trabalhe como se o trabalho servisse para alguma coisa".
} 


\section{O brincar, a festa, a dilapidação}

Com Winnicott (1971), demo-nos conta da importância do brincar (play) na formação da criança. Todos os pais ("suficientemente bons" [Winnicott]) estão convencidos disso, bem como (felizmente) muitos pedagogos. ${ }^{11}$ Os adultos não ficam atrás. Jogos de cartas, jogos de puro azar, jogos esportivos (de competição ou de massa, como, por exemplo, a maratona), atraem sua atenção até na velhice. A tal ponto que um especialista do jogo, como Caillois (que consagrou um livro a este tema e organizou o volume da Pléiade sobre "os jogos"), também pode escrever, evocando as diferenças culturais: "Diga-me com o que brincas, e te direi quem és" (1958).

Não só os jogos atraem os homens, mas também a dança (de salão, esportiva, o "hip hop" etc.), o canto (a quantidade de cantores nos corais está em constante progressão) e as comemorações - basta contarmos a quantidade de feriados (noventa) até o advento da Revolução Francesa e as comemorações atuais, que tendem a se multiplicar pelas mais diversas razões e durante as quais se dilapidam energia, álcool, dinheiro, drogas, fumo... (comemorações que às vezes acabam mal), para nos darmos conta de que as pessoas buscam o convívio, a vertigem, a música enlouquecedora, os jogos de luzes. Em uma palavra, a embriaguez.

Roger Caillois, assim como Georges Bataille (1957), e, antes deles, Johan Huizinga (1938), tiveram razão de dizer que, sem as festas, os homens se sentiriam profundamente amputados. Ora, a festa é, por definição, o oposto do trabalho. Ela sempre marca o fim do "tempo do desgaste" (Caillois, 1938) e o desejo de renovação, o tempo em que se pode deixar levar, não ser sério, e, se necessário for - como diz o adágio popular - "dar uma de doidão". Enfim, deixar o racional da vida cotidiana para se entregar ao irracional, ao emocional e aos excessos. Mas é preciso mencionar que, após todas as atividades citadas até agora, os indivíduos são obrigados a descansar (de modo irreverente, Malevitch, 1921, indica que Deus, após seis dias de trabalho, vai descansar definitivamente) e passam cerca de um terço de suas existências dormindo.

\section{A guerra}

Não há tribo, não há polis, não há sociedade sem guerra. Clastres notava que o prazer essencial dos Guaranis era a guerra; os especialistas da democracia ateniense sempre destacaram seu caráter profundamente agonístico. Todas as sociedades fizeram a guerra em determinado momento, guerra contra o inimigo ou guerra civil. Desde que os historiadores existem, não conseguiram encontrar, no mundo, um dia sem guerra. As forças de morte (as pulsões de morte) estão sempre operantes. Agora sabemos que o ódio, que constitui o objeto, é anterior ao amor, que a violência originária (Aulagnier, 1975) ou fundamental (Bergeret, 1984) está presente desde os primeiros dias da criança, que a destruição (que muitas vezes está bem longe de ser "criadora") é constante (a reconstrução gera novos investimentos e acelera o crescimento).

As crianças gostam de brincar de guerra e às vezes os adultos abusam disso, levando-as a participar de guerras verdadeiras. A desolação e a devastação são mais frequentes do que o ganho, a renovação. Afinal de contas, antigamente os heróis eram, na maioria das vezes, "guerreiros", e agora são substituídos por mísseis e drones muito mais destruidores. A ideia de um mundo sem guerra está definitivamente descartada, ainda mais que determinadas pessoas encaram a guerra como um trabalho "como qualquer outro." 12

11 Não podemos nos esquecer de Freud (1920), que demonstrou, em seu texto a respeito da "brincadeira do carretel", pontuada pelo "Fort-Da" da criança, que essa brincadeira permitia aceitar a ausência da mãe e favorecer o aprendizado da noção do diferido ou ausente.

12 É inútil nos aprofundarmos nesse tema. Os "pacifistas” agora sabem que suas ações jamais levarão à paz universal sonhada por Kant ou Rousseau. No entanto, é preciso lutar contra as tendências à guerra, e, sempre que possível, ajudar na construção de "laços 
Concluindo esta primeira parte, podemos confirmar nossa proposta inicial: o trabalho não constitui a essência do homem, ainda que tenha se tornado, nos tempos modernos, o mais importante de seus atributos ou, pelo menos, um de seus atributos essenciais. Agora, temos de nos perguntar: o que é o trabalho?

\section{O que é o trabalho}

Para responder a essa pergunta, não é inútil voltar ao "original" e lançar mão dos grandes filósofos Platão e Aristóteles. ${ }^{13}$

Para Platão, o conhecimento do absoluto é essencial e primeiro. Ele consiste, essencialmente, na contemplação das formas e das ideias, ou seja, dos modelos inteligíveis da realidade sensível - em primeiro lugar, na contemplação da Ideia do Bem. Daí vem a primazia, para ele, do saber sobre a ação. ${ }^{14}$

Aristóteles será mais útil ao nosso propósito. Ele distingue várias formas de ação, que remetem a várias partes da alma. Existe, em primeiro lugar, uma ação puramente racional que se divide em ação teorética, semelhante à ação teórica de Platão: é preciso primeiro contemplar (é o sentido primeiro do termo "teoria"). Isso é necessário para conhecer o que é e para uma ação calculadora. Esta diz respeito ao contingente que implica sempre deliberação (interna ou de várias vozes) e decisão, que deve ser concretizada na forma de uma ação sobre o mundo.

Essa última forma da ação (à qual nós modernos chamamos simplesmente de "ação") é dividida em praxis e poiésis. A práxis é um agir cujo objetivo reside no exercício prático da própria atividade (a política, a medicina ou a educação, às quais podemos acrescentar, particularmente, o jogo e o esporte). A práxis é "interessante não porque produz, mas porque manifesta a identidade daquele que age" (Arendt, 1958). No entanto, tal visão não é suficiente, pois a práxis tem sempre uma relação com o humano. Por isso, é indispensável completá-la, conforme Castoriadis, que a considera sempre ligada à imaginação coletiva. Para Castoriadis (1975), é "este fazer no qual o outro ou os outros são vistos como seres autônomos e considerados como agentes essenciais do desenvolvimento de sua autonomia, pois as pessoas já são parcialmente autônomas" (os membros do povo, os doentes, os analisantes, os alunos). ${ }^{15}$ Ela visa, portanto, à emancipação humana; é por isso que a luta de classes e a resistência são praxis por excelência.

A Poiésis é uma noção profundamente ambígua. Por um lado, ela se exprime no mundo da produção de objetos, de ferramentas (portanto, é algo exterior ao humano, contrariamente à práxis), da técnica (ou seja, de todos os métodos e meios usados para atingir um fim preestabelecido, com normas e regras a serem respeitadas, para evitar, tanto quanto possível, as resistências e aquilo que chamamos de "efeitos perversos"). Mas, por outro lado, ela se revela na atividade criadora (escrita, música, pintura, escultura, arquitetura etc.), que, muitas vezes, como evoca Castoriadis, são criações "ex nihilo", expressão do "imaginário radical".

A arte (o conjunto das atividades artísticas) é uma reconstrução do mundo, e sempre expressou (até mesmo durante a Idade Média, período no qual as regras eram codificadas e

afetivos positivos” entre futuros adversários. Mas não se deve manter grandes ilusões sobre as felizes consequências dessas ações em favor da vida.

13 Não se trata de injuriar os "pré-socráticos", omitindo Parmênides, Heráclito e Empédocles, já que, nos fragmentos que restam de suas obras, o trabalho é pouco ou nada mencionado.

14 É contra essa "torsão platônica” (Castoriadis) que Marx se levanta, querendo elaborar uma crítica em ato. Lembremo-nos de suas frases famosas: "a arma da crítica não pode substituir a crítica das armas" e "passar da interpretação do mundo a sua transformação".

15 Castoriadis escreve: “a pedagogia não é nem um reflexo nem uma técnica, pois não se pode elucidar totalmente o jogo pedagógico, que é uma relação”. Pode-se dizer o mesmo da política, da medicina e da psicanálise. Ver, a esse respeito: Cifali, Cournut, Enriquez \& Fain, 1987. 
imperativas) a capacidade daqueles que criam a obra de "desviar" dos modelos impostos, de inventar detalhes imprevistos ou ousar, às vezes, incríveis transgressões. Os artistas sempre foram, em determinados aspectos, Dichters, como mencionamos anteriormente, aqueles que (pelo menos os melhores dentre eles) nos transformaram, encantaram, levantaram, entusiasmaram. ${ }^{16}$ Ora, como está isso atualmente? A arte contemporânea entrou totalmente no mundo marchand, do qual Jeff Koonf e Damien Hirst são os exemplos mais espetaculares. Cada vez mais, o artista quer ter sucesso mais rapidamente e criar (!) aquilo que o mercado lhe pede. É claro que nem todos são assim, mas a maioria é. Eles se tornam, ainda que pensem e digam o contrário, simples produtores.

Ao observarmos a produção, vemos que ela não só coloca no mercado produtos cada vez mais rapidamente degradáveis (e sem possibilidade de conserto), objetos muitas vezes totalmente inúteis, ainda que astuciosamente executados; ela também codifica leis, normas, regras, conjuntos de procedimentos que sufocam qualquer insinuação de criação (vejam simplesmente os absurdos procedimentos de avaliação de "performance" das universidades e dos professores, cujo único resultado é reprimir a desordem. ${ }^{17} \mathrm{Em}$ outras palavras, fazer desaparecer qualquer criatividade).

Se pelo menos essa produção fosse relativamente planejada, em um mundo estável e no qual os trabalhadores pudessem ter tempo para aprender seu ofício, inventar suas "astúcias", afastar-se do trabalho prescrito, ${ }^{18}$ transmitir seu saber, viver dentro de coletividades responsáveis, ser reconhecidos em suas competências, a situação ainda seria difícil, mas aceitável. Mas não é mais o caso. Os projetos estão sempre mudando, as ordens geram contraordens, as empresas estão fechando ou sendo compradas, o culto à performance e à urgência está reinando, os coletivos estão se rompendo, o "estresse profissional" e até mesmo o assédio se tornam uma realidade cotidiana. Os ricos enriquecem e os pobres empobrecem.

É desnecessário continuar. Todos têm consciência da degradação das condições de trabalho e do aumento da precariedade (De Gaulejac, 2011). Por conseguinte, o trabalho exprime a exploração das pessoas (em um mundo em que só o lucro é respeitado, cada indivíduo "subalterno" é colocado em situação de angústia, por medo de perder sua posição, e é obrigado a aceitar o salário insuficiente ou até mesmo o péssimo emprego que lhe oferecem, sob pena de tornar-se um sem-teto. Jamais a exploração foi tão franca e tão cínica). ${ }^{19}$

Já a alienação nunca foi tão intensa. Se a autonomia (a emancipação humana) é a capacidade de situar-se no mundo, de apropriar-se dele, de construí-lo pela práxis, de dar-lhe sentido, de construir nossa identidade conforme nossa ressonância no mundo (G. Amado), de mergulhar em experiências que deixam vestígios significativos em nossas vidas (o que os alemães chamam de "Erfahrungen") ${ }^{20}$, de poder entrar em relação e de poder "amar" tudo o que é amável e permite que nos questionemos, nos formemos, cresçamos, podemos dizer, infelizmente e sem hesitação, que o projeto de autonomia individual e coletiva, do qual Castoriadis foi mensageiro, está indo de mal a pior, e que a alienação está se tornando nossa realidade cotidiana e, a práxis, uma espécie de "antiguidade" da qual ainda se fala, mas que não penetra mais nossa prática diária. Recentemente, Helmut Rosa, em suas obras a respeito do processo de

16 Como Rilke diz admiravelmente em suas cartas sobre Cézanne: "As obras de arte sempre são produtos de um perigo que se correu, de uma experiência levada a cabo, até ao ponto em que o homem não pode mais continuar". Isso se aproxima de uma frase de Picasso: "Se não houvesse angústia por trás destas maçãs, Cézanne não me interessaria mais do que Bougereau".

17 Paul Claudel escreveu esta magnífica sentença em seu prefácio ao Soulier de satin: "Se a ordem é o prazer da razão, a desordem é a delícia da imaginação".

18 Eles ainda podem fazer isso, ainda que pouco, já que o trabalho real nunca é a cópia do trabalho prescrito. Desde Elliott Jaques, Cornélius Castoriadis, Christophe Dejours, Yves Clot e Dominique Lhuilier, nós já sabíamos disso. No entanto, as zonas de liberdade estão cada vez menores e os trabalhadores devem, cada vez mais, ser resistentes. E isso não é nada fácil.

19 Apesar dos esforços dos defensores da economia solidária e dos poucos "patrões" que ainda têm a "fibra social".

20 Mais essenciais que as Erlebnissen, caras (durante muito tempo) aos psicólogos que indicam “episódios de experiências vividas”, mas que podem não deixar qualquer vestígio. 
aceleração da história, demonstrou que, se para Marx a alienação dos homens se dava com relação às ações, ${ }^{21}$ aos produtos (já que a produção escapa de suas mãos), à natureza (rejeitada pelo mundo técnico), ela atualmente afeta também o espaço, o tempo, os outros, a relação que os seres humanos têm consigo mesmos e, no final das contas, o mundo vivido, já que este se torna uma terra de "silêncio".

Práxis apagada, criação diária de mais "mercadorias", produção (e naturalmente, também, como corolário, consumo em demasia), tudo isso nos afasta do mundo (no qual tende a reinar a desolação) e de nós mesmos. A alienação está em toda parte, e a autonomia se tornou, se não impossível, pelo menos extremamente difícil.

O que fazer, então? Gostaríamos de evocar agora as condições de um trabalho criativo (integrando a práxis) sem muitas ilusões com relação a seu caráter realista. Talvez estejamos na esteira da utopia, mas, como já dissemos, "as sociedades que não sonham são sociedades que morrem".

\section{As condições para o trabalho não alienado}

a) Jamais confundir, como indica Dominique Lhuilier (2006), trabalho assalariado, atividade e emprego. O trabalho assalariado implica o conhecimento de um ofício para o qual foi necessário algum aprendizado anterior (ou que vai ser adquirido "pela experiência", no melhor dos casos graças à ajuda de um colega mais experimentado) e que permita que o trabalhador demonstre que tem imaginação e que sabe "se virar", que ele enfrente o "real do trabalho" (sempre diferente do "trabalho prescrito"). As atividades (por exemplo, os "trabalhos domésticos", a bricolagem etc.) "não são lazeres, mas assumem as mesmas funções do trabalho no sentido usual do termo: funções utilitária, social e identitária." ${ }^{22} \mathrm{O}$ emprego está sempre dentro de uma organização. É enquadrado por normas, regras e procedimentos. Apresenta-se como experiência fundamental de assujeitamento. A atividade exprime as possibilidades humanas; o trabalho assalariado, a possibilidade, apesar das limitações (e de seu caráter "alienado"), de demonstrar iniciativa; o emprego só significa, para a maioria das pessoas em busca dele, a sobrevida biológica ou social;

b) Fazer corretamente seu trabalho, mas nunca exagerar no zelo - não investir totalmente no trabalho, ter sempre outros centros de interesse, ainda que "se tenha sucesso" em sua função e que se tenha uma bela carreira. Como dizia, com humor, Marilyn Monroe: "uma carreira é ótima, mas ela não pode aquecê-la numa noite fria, quando você está sozinha na cama”. Quantas pessoas devotadas e fiéis à sua empresa, que não contam suas horas de trabalho, descobrem, um dia, que acabaram com suas famílias, esqueceram-se de criar seus filhos e estes, por isso mesmo, experimentam grande ressentimento. Essas pessoas jamais puderam realizar o menor de seus desejos e acabam sozinhas, sem cônjuge, sem filhos e... às vezes, são brutalmente despedidas da empresa. Essas pessoas perderam tudo, pois acreditaram (o que ainda era verdade há uns trinta anos) no mito do "homem da organização" (que dá sua força e sua vida à organização e é recompensado por ela). Nesse ponto, Crozier (1986) tem razão. $\mathrm{O}$ único que se sai bem nessa situação é aquele que se situa no cruzamento de diferentes domínios, meio independente, ou seja, o homem que certamente faz seu trabalho bem feito, mas que também faz parte de outros grupos e se mantém disponível para seus próprios desejos, como sua única maneira de "respirar" e de durar;

21 Rosa precisa (2005): "não fazer o que se quer fazer e não querer fazer o que se faz (quando se é obrigado a fazê-lo, como, por exemplo, esses diretores de recursos (!) humanos que tem de elaborar, ainda que não concordem com eles, 'programas de desligamento' [repetidas vezes])".

22 Yves Clot, por sua vez, baseando-se em uma citação de Vygotski, "o homem está cheio, a cada minuto, de possibilidades não realizadas", escreve: "o real da atividade é também o que não se faz, o que não se pode fazer, o que se busca fazer sem conseguir... Devemos acrescentar o que se faz para não se fazer o que tem que ser feito, ou ainda o que se faz sem querer fazer. Dessa forma, a atividade possui um volume que ultrapassa a atividade realizada" (citado por Lhuilier, 2006). 
c) Saber situar-se na organização. Saber entender sua posição, suas possibilidades reais (e não fantasiosas) de ter acesso a trabalhos interessantes, de se aperfeiçoar. Para isso, é indispensável uma comparação entre nossos próprios valores e normas e os da organização, da instituição ou grupo do qual participamos. Isso nos permite conhecer melhor as categorias que nos fazem pensar e agir;

d) Lutar contra a submissão (“a servidão voluntária”), todos os dias ou em determinados momentos (greves), já que os superiores sempre têm tendência (ainda que não tenham consciência disso) a abusar de seu poder. Para isso, é necessário criar (ou pertencer a) um coletivo bem organizado. O trabalho, ainda quando realizado solitariamente, sempre é a expressão de um coletivo de pensamento e de ação. Sozinha, a pessoa não pode se opor às ordens às vezes absurdas ou propor suas ideias e maneiras de fazer. Os dirigentes atuais sabem muito bem disso, e tentam fazer os coletivos desaparecerem;

e) Saber calcular (a razão calculadora de Aristóteles, o reckoning de Hobbes e Thoreau) entre o que se ganha e o que se perde a cada momento durante seu investimento no trabalho. Ser extremamente lúcido em relação a isso. $O$ fato de calcular não esvazia a questão do sentido que se deve dar ao trabalho. Um trabalho sem sentido não passa de um trabalho alienado;

f) Jamais ceder às tendências sacrificiais (toda organização exige de seus membros certa dose de "masoquismo funcional") que se traduzem por sentimentos de culpa por parte desses membros, ou, mais frequentemente nos dias atuais, de vergonha, já que os ideais do eu da organização, interiorizados pelos funcionários, prevalecem sobre a relação com o supereu individual;

g) Querer ser reconhecido (desejo de reconhecimento pelo outro - a luta pelo reconhecimento, como já sabemos desde Hegel, está no centro da vida - e reconhecimento de seu próprio desejo). Mas jamais ficar obcecado por isso. Muitas vezes, os desviantes, os marginais, é que são os verdadeiros criadores, os que trazem algo novo à organização ou ao ofício. ${ }^{23} \mathrm{O}$ risco é de ser mais ou menos "marginalizado" pelos outros e se ver rejeitado. Cada um deve avaliar os riscos que pode ou quer correr, as transgressões que pode se permitir;

h) Ter condições de se questionar, de dar-se conta de sua finitude, de elucidar sua conduta, de ser estrategista relativamente aos que tentam nos manipular e também ser capaz de sublimação; ${ }^{24}$

i) Em poucas palavras, tomar o caminho da vida e se manter nele, apesar de seu aspecto árido e árduo. Aí repousa o caráter essencial de vários elementos evocados na primeira parte deste estudo e que devem modular a relação com o trabalho: o gosto pelo ócio, pela perda de tempo, pelo jogo, pela caminhada, pela imaginação ("o que agora está provado primeiro foi imaginado", escreveu magistralmente William Blake), pela festa, pelo vazio em vez do cheio ${ }^{25}$ e pela recusa à seriedade, que nada mais é do que tédio (Montaigne ${ }^{26}$ e Mallarmée ${ }^{27}$ podem ser notáveis guias nesse aspecto).

23 Robert Park (da Escola de Chicago) dizia: “O homem marginal é sempre um ser mais civilizado do que os outros”.

24 A sublimação autoriza a psique a se destituir de seus objetos próprios de prazer em benefício de objetos sociais valorizados pela cultura; ela se apresenta como experiência intrapsíquica na qual a subjetividade está totalmente engajada e se exprime através da busca de uma verdade partilhada.

25 Aludimos aqui ao não agir (ao wu-wei dos taoistas), que não significa ausência de ação, mas ação rara e pensada, que concorre para a harmonia do mundo, bem como para a pertinência da não ação, nos casos em que toda ação imediata e reativa teria resultados catastróficos (é o agir do não agir). Os "subalternos” nem sempre percebem o valor da "não ação". É por isso que Lie Tse (autor do Tratado do vazio perfeito) pode escrever: "Os povos não percebem a existência dos grandes soberanos. Mas se apegam e rendem louvores aos menores".

26 Montaigne escrevia: "quando estou dançando, estou dançando", indicando que era capaz de se entregar totalmente a seu prazer. Escreveu também: "Se você quer colher repolhos, tema o granizo. Portanto, aja não pelo fruto esperado, mas pela própria ação" (Viva por viver).

27 Não nos esqueçamos de que aquele que pretendia ser um poeta puro, Mallarmé, assinava colunas de moda sob o pseudônimo Marguerite de Ponty na revista La Dernière mode. 
Para fecharmos este artigo, gostaríamos de fazer algumas observações:

a) É preciso, em várias circunstâncias, relativizar o que se diz sobre as oposições frontais entre dirigentes e colaboradores, pois às vezes o próprio chefe de empresa é obrigado a fazer mudanças, reestruturações em sua organização e, por outro lado, os colaboradores podem, pelo fato de sua submissão, pelo desejo de serem notados e apoiados por seu chefe, participar da má gestão e do clima negativo da organização. Ninguém é perfeitamente branco ou preto. Assim, a estrutura capitalista e seus principais atores, os proprietários, acionistas, empresários e banqueiros, continuam sendo os principais responsáveis pela crise e pelo sofrimento no trabalho;

b) Ainda que, nas condições enumeradas, tenhamos várias vezes feito referência ao trabalho assalariado nas organizações, o que escrevemos também é válido para qualquer pessoa que trabalhe, ainda que exerça uma profissão liberal;

c) É claro que as condições não podem ocorrer todas ao mesmo tempo e que, muitas vezes, somente algumas delas estarão reunidas. Além disso, qualquer lista (que certamente não é exaustiva), qualquer enumeração, falsifica a complexidade da realidade e silencia as interações entre as diversas condições. A expressão linear é sempre perigosa. Infelizmente, se quisermos nos expressar claramente por escrito, somos condenados a utilizá-la;

d) Enfim, é claro (e o leitor perceberá isso sem dificuldades) que manifestamos neste texto (e até mesmo argumentamos) nossas preferências. Nossa concepção do homem é a de um ser livre criador de uma obra ${ }^{28}$ (de qualquer natureza: de um livro ou da fundação de uma família feliz) e que trabalha (no sentido do trabalho alienado ${ }^{29}$ ) o mínimo possível. Tal ser (que caminha para a autonomia) é raro, pois nossa sociedade permanece profundamente heterônoma e produtivista. É por isso que todos os que podem situar-se como "exotas", excêntricos, marginais, dichters, autônomos, não devem, do nosso ponto de vista, abandonar a luta contra a heteronomia, devem "nadar contra a corrente" e sair da "insignificância" (Castoriadis, 1996). Assim, talvez eles abram a porta pela qual outros possam entrar, a fim de favorecer não o advento de um "futuro radioso", mas simplesmente (e já é muito) de uma sociedade na qual seja mais fácil viver e que seja mais justa, uma sociedade na qual trabalhar se torne uma atividade nobre, através da qual todos poderão realizar seus desejos e sua vontade de ser um homem (no sentido genérico da palavra) que pensa, busca, age, afirma sua identidade sempre em evolução e traz sua contribuição, sempre limitada, mas essencial, para a transformação de um mundo do qual ele se sinta parte.

\section{Referências}

Amado, G. (1993). La résonance psychosociale. Thèse Université, Paris 7.

Arendt, H. (1958/1961). La condition de l'homme moderne. Paris: Calmann-Lévy.

Bataille, G. (1930/1984). La notion de dépense. In La part maudite (pp. 21-38). Paris: Éditions de Minuit.

Bataille, G. (1957). L'érotisme. Paris: Éditions de Minuit.

Bergson, H. (1932). Les deux sources de la morale et de la religion. Paris: PUF.

Caillois, R. (1938). L'homme et le sacré. Paris: Gallimard.

28 Que opta mais pelo poder (viver na tensão ocasionada pelo trabalho da obra) do que pelo prazer (constantemente ligado à redução da tensão), como esses grandes artistas que nunca estão satisfeitos com suas obras e sempre querem "fazer melhor" (como Cézanne, descrito por Rilke, que "durante os últimos anos de sua vida não fez outra coisa senão trabalhar sem alegria, aliás, tomado por uma ira permanente, irritado com cada uma de suas obras").

29 A desalienação total é impossível, já que, como diz tão bem Lévi-Strauss (1950): "[...] propriamente falando, é aquele que denominamos saudável de espírito que se aliena, pois ele consente em existir num mundo que só pode ser definido pela relação do eu com o outro". 
Caillois, R. (1958). Les jeux et les hommes. Paris: Gallimard.

Canguilhem, G. (1966). Le normal et le pathologique. Paris: PUF.

Castoriadis, C. (1975). L'Institution imaginaire de la société. Paris: Seuil.

Castoriadis, C. (1978). Les carrefours du labyrinthe. Paris: Seuil.

Castoriadis, C. (1996). La montée de l'insignifiance. Paris: Seuil.

Castoriadis, C. (1999). Figures du pensable. Paris: Seuil.

Clastres, P. (1974). La société contre l'Etat. Paris: Seuil.

Cournut, J., Cifali, M., Enriquez, E. \& Fain, M. (1987). Les trois métiers impossibles. Paris: Les Belles Lettres.

Crozier, M. \& Friedberg, E. (1986). L'acteur et le système. Paris: Seuil.

Dumezil, G. (1940). Mitra-Varuna. Paris: Gallimard.

Enriquez, E. (1971). De la horde à l'Etat. Paris: Gallimard.

Enriquez, E. (2012). Les tumultes de l'amour. Paris: Parangon.

Freud, S. (1920/1981). Au-delà du principe de plaisir. In Essais de psychanalyse (pp. 41-116). Paris: Payot.

Freud, S. (1927/1994). L'avenir d'une illusion. Paris: PUF.

Gaulejac, V. (2011). Travail, les raisons de la colère. Paris: Seuil.

Lafargue, P. (1880/2009). Le droit à la paresse. Paris: Allia.

Lévi-Strauss, C. (1947). Les structures élémentaires de la parenté. Paris: PUF.

Lévi-Strauss, C. (1950). Introduction à l'œuvre de M. Mauss. In M. Mauss, Sociologie et anthropologie (pp. IX-LII). Paris: PUF.

Lhuilier, D. (2006). Cliniques du travail. Toulouse: Érès.

Malevitch, K. (1921/1995). La Paresse comme vérité effective de l'homme. Paris: Allia.

Malinowski, B. (1922/1989). Les argonautes du Pacifique Occidental. Paris: Gallimard.

Marx, K. (1846/1982). L'idéologie allemande. In K. Marx, Euvres complètes (Tome III, pp.1087-1325). Paris: Gallimard.

Mauss, M. (1924/1950). Essai sur le Don. In M. Mauss, Sociologie et anthropologie (pp. 144-279). Paris: PUF.

Rosa, H. (2005/2010). Accélération. Paris: La Découverte.

Roy, C. (1978). Les séquestrés de la croyance. Nouvelle Revue de Psychanalyse, 18, 99-109.

Russell, B. (1932/2010). Eloge de l'oisiveté. Paris: Allia.

Spitz, R. \& Goldiner, W. (1950). De la naissance à la parole. Paris: PUF.

Starobinski, J. (1974). Je hais comme les portes d'Hadès, Nouvelle Revue de Psychanalyse, 9, 7-21.

Steiner, G. (1997). Passions impunies. Paris: Gallimard.

Stevenson, R. L. (1877/2011). Une apologie des oisifs. Paris: Allia.

Thoreau, H. D. (1894/1996). Walden ou la vie dans les bois. Paris: Gallimard.

Winnicott, D. W. (1971/1975). Jeu et réalité. Paris: Gallimard.

Zaltzman, N. (1998). La guérison psychanalytique. Paris: PUF. 